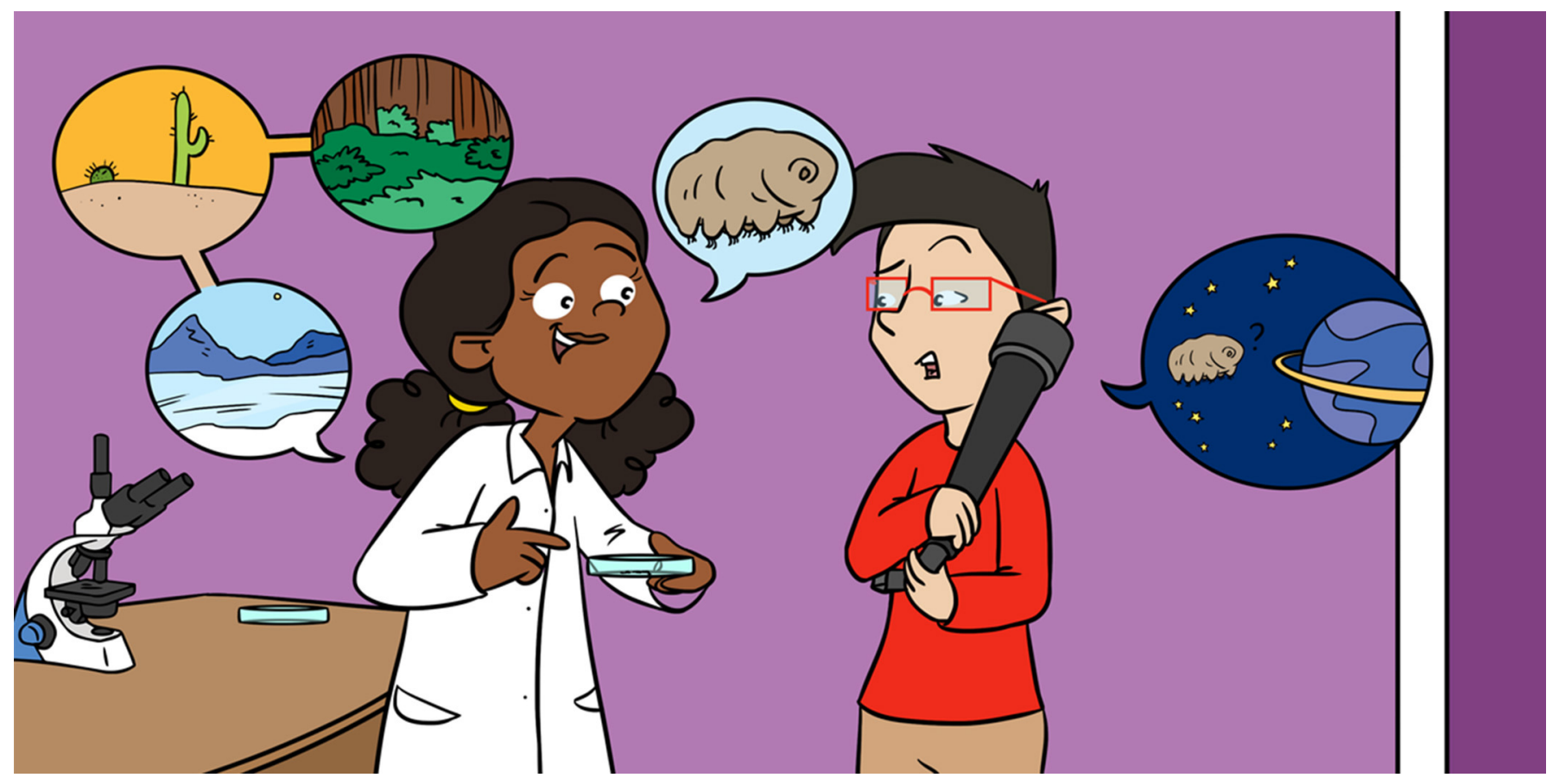

\title{
WATER BEARS-THE MOST EXTREME ANIMALS ON THE PLANET (AND IN SPACE!)
}

\section{Skander Elleuche *}

EUROIMMUN Medical Laboratory Diagnostics AG, Lübeck, Germany

\section{YOUNG REVIEWERS:}

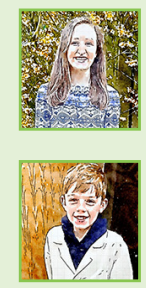

CATHERINE

AGE: 15

HARRISON

AGE: 11

ISABEL

AGE: 11

MARGARIDA

AGE: 13

MEGAN

AGE: 15
Can you imagine that there is an eight-legged bear that tolerates colder temperatures than the polar bears do in the Arctic? Can you imagine that this bear is able to grow older than the grizzly bears in North America? And can you imagine that this bear grows by molting, like spiders or snakes? These so-called water bears, scientifically named tardigrades, are the most extreme animals on our planet. They not only survive in ice, but also in boiling water. Moreover, they can stop breathing for long periods and they have even traveled to outer space, surviving without an astronaut's suit. Since water bears can withstand the harshest conditions on earth and beyond, they may teach us how we can protect ourselves from extreme environmental conditions.

\section{ARE WATER BEARS TRUE BEARS?}

What are water bears? Are they really bears? This question is easy to answer: no, the only thing that water bears and bears have in common is the fact that both are animals. The shape of a water bear slightly 
Figure 1

Water bears, also called tardigrades, are extremely small compared to other animals. This image of a water bear was taken with a scanning electron microscope. The water bear micrograph by Bob Goldstein and Vicky Madden

(https://en.wikipedia.org /wiki/Tardigrade\#/media /File:Waterbear.jpg). Photographs of the grasshopper and the cat by S. Elleuche.

\section{ARTHROPODS}

This group of animals is characterized by the outer skeleton and includes insects, spiders, millipedes, and crabs.

\section{WETLAND}

A living space for multiple organisms that is temporary or permanently flooded by water and inhabited by aquatic plants.

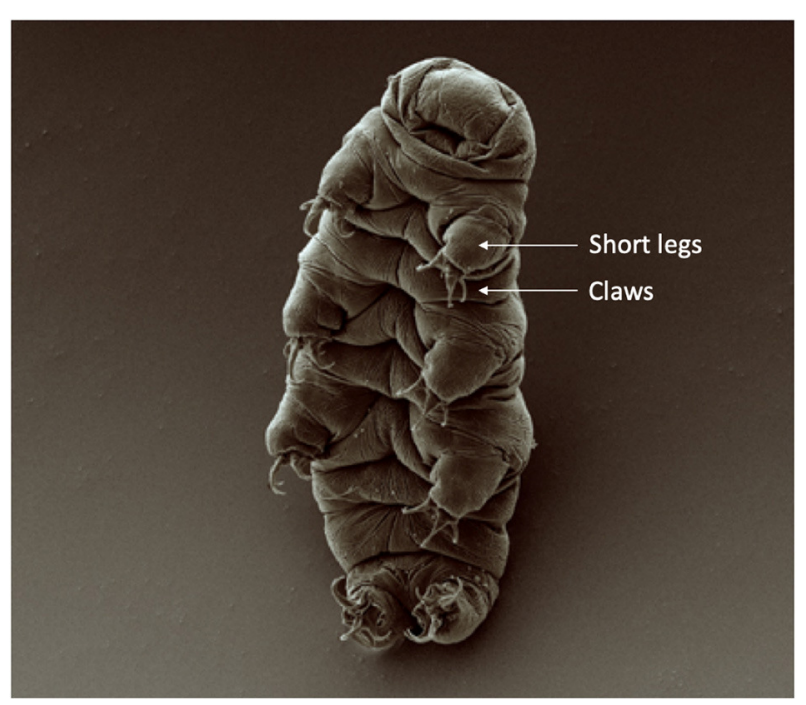

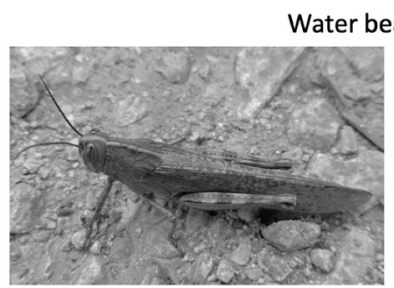

Grasshopper ( $5 \mathrm{~cm}$ )

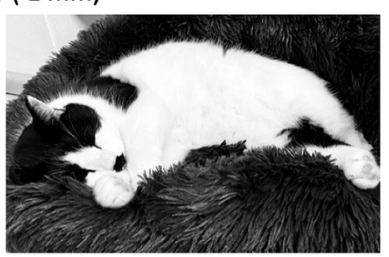

Our cat $(58 \mathrm{~cm})$

resembles that of true bears, such as the polar bear or the grizzly, but they are most closely related to the huge group called the arthropods, which includes insects, spiders, millipedes, and crabs. However, you cannot see a water bear with the naked eye, because these animals are very tiny. They usually grow to $<1 \mathrm{~mm}$ (Figure 1). Water bears were discovered more than 200 years ago [1]. The German pastor and biologist Johann Goeze initially named them "little water bears," because of their size and their preference for wet living spaces.

Water bears love wet or at least humid environments where they can remain covered by a layer of water. They are among the most successful lifeforms known and are widely distributed all over our planet. We can observe water bears in all oceans, rivers, seas, and lakes, and in wetlands, but they are mainly found in mosses or swamps. Water bears have even conquered the highest mountains, rainforests, and Antarctica. Many different types of water bears have been found and described. They even conquered Hollywood, where you may have encountered water bears in the Marvel superhero movies "Ant-Man" and "Ant-Man and the Wasp," when Scott Lang disappears into the quantum realm.

Water bears have a strange shape-they are of stout build with four pairs of short and stubby legs, ending with four to eight claws, and they appear to lumber along as they move (Figure 1). The first three pairs of legs are used for moving, while the water bears use the last pair of 


\section{TARDIGRADE}

A scientific nomenclature for a group of animals that are also known as water bears or moss piglets.

\section{MOLTING}

Some animals, such as water bears, insects, spiders and snakes do not grow continuously They have to replace their outer sheath when it became too tight.

\section{DORMANCY}

Death-like resting stage during which each kind of activity such as growth or ingestion is temporarily stopped. legs to hang on to the surface on which they walk. Even with so many legs, water bears usually do not walk but instead passively slide, using the flow of water or wind. The way they move is also reflected by their scientific name: tardigrades. Tardigradum means "slow walker," and this name was given to water bears by Loredano Spallanzani, a former Italian biologist, due to the slow and sedate behavior of these animals, which might look like laziness.

\section{HOW DO WATER BEARS GROW?}

Just like almost any other creature on our planet, water bears must eat food and breathe air to generate the energy needed for their cells to divide and their bodies to grow. In contrast to true bears, water bears are just too tiny to eat salmon or seals. Honey is also not on their menu. Nevertheless, water bears basically eat everything. While they mainly prefer vegetarian foods like plants and algae, they will also eat microscopic animals.

Unlike most other animals, the bodies of water bears are created following a specific plan. Every type of adult water bear even has exactly the same number of cells. Their cells are continuously dividing, but the water bear is covered by a non-growing and non-flexible sheath, or protective outer covering. As soon as the sheath becomes too tight, water bears will shed the sheath in a process called molting, similar to spiders and snakes. Although both humans and water bears need oxygen to survive, water bears do not breathe the way we do. In fact, they do not even possess respiratory organs like lungs. Water bears take up air through the surfaces of their bodies, just like insects. Water bears can even stop breathing and eating for some time, similar to the process of hibernation that allows other animals, such as polar bears, to slow down their bodily processes to survive the winter months. However, water bears are even more impressive, because not only can they sleep for a couple of months, but they can also become extremely old and thrive in the most extreme places on earth.

\section{WHAT ARE THE MOST EXTREME LIVING SPACES FOR WATER BEARS?}

Water bears are the most extreme animals that we know-they basically tolerate almost every extreme condition that we can think of. They can survive in the Arctic alongside polar bears, or in Antarctica, where penguins feel at home (Figure 2A). Water bears even survive in the laboratory at temperatures below $-200^{\circ} \mathrm{C}$, which is more than twice as cold as the coldest temperature that was ever observed in nature. Under such extreme conditions, the water bears enter a stage that resembles death. During this death-like resting stage, called dormancy, water bears stop all functions that usually define life: they stop breathing, they stop moving and growing, and they even stop 
Figure 2

(A) Water bears can survive in extremely cold habitats, like the icy Himalaya mountains, and at temperatures as low as $-150^{\circ} \mathrm{C}$. (B) Water bears can survive in extremely hot habitats, like the hottest deserts, and at temperatures as high as $100^{\circ} \mathrm{C}$. (C) Water bears can even survive in the vacuum of space!

\section{EXTREMOPHILES}

Microorganisms that love to live in the most extreme environments on the planet. Water bears are no true extremophiles because, although they can tolerate extreme conditions, they do not prefer

such environments.
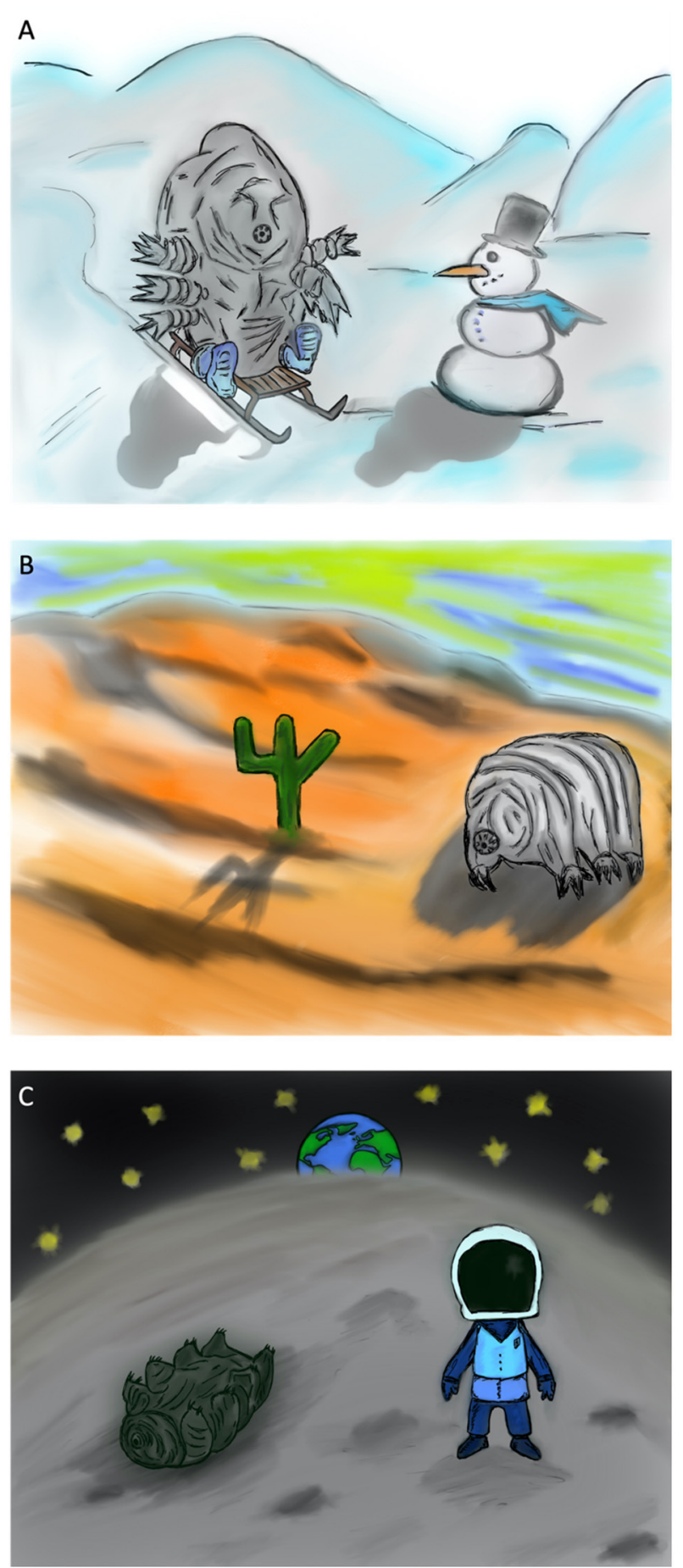

Figure 2

digesting their last meal [2]. Depending on how long they are in dormancy, it can take several hours to wake them up. Some water bears have even been seen to last for a century in dormancy.

On the other end of the temperature scale, there are microbes that can grow at temperatures around $120^{\circ} \mathrm{C}$. These heat-loving microbes are called extremophiles [3,4]. Water bears do not love the extreme 
heat, but not only can water bears survive in the desert, they can even tolerate temperatures around $150^{\circ} \mathrm{C}$ (Figure 2B)-temperatures that would kill most extremophiles. Even more impressive is the fact that water bears can be repeatedly heated up and frozen without dying. These abilities have allowed water bears to become unrivaled in their success over the course of evolution. More than 1,000 different types of water bears are known, with the oldest species dating back more than 500 million years.

Water bears do not only survive the coldest cold or the hottest heat without food and without air to breathe, but they can also go without water and they are resistant to radiation. Since those extreme conditions exist in space, scientists asked themselves whether water bears might even be able to travel in space (Figure 2C). Scientists knew that the high pressure present in the deep sea could be tolerated by water bears, but in space there is a vacuum, with lower pressure compared to earth. Nevertheless, several species of water bears were sent into space and all of them returned home in healthy condition. Moreover, more than 1,000 water bears in dormancy were crash-landed on the moon as passengers of a spacecraft in 2019. It is expected that most of these robust animals have survived the crash and could be revived by water and oxygen in the future.

\section{COULD WATER BEARS BE USED TO HELP HUMANS?}

For a long time, scientists have been trying to understand the water bears' resistance to radiation. Although radiation in the form of X-rays

\section{GENOME}

A kind of construction plan that is included in every living cell in all organisms (Bacteria, Fungi, Plants, Animals etc.), which determines the look and composition of most cellular compon. can be used by doctors to examine broken bones, radiation can also cause the destruction of the body's instruction manual. This instruction manual is called the genome, and it is similar in every living organism on earth, including water bears. There must be a reason for the immense resistance to radiation seen in water bears, which is more than 1,000 times higher than humans' resistance.

One part of the genome of water bears has recently been identified and reproduced in a laboratory [5]. When this factor was added to human cells grown in the same laboratory, the human cells tolerated more intense radiation than did human cells without the water bear factor. These early experiments may lead to future applications of water bear factors that could not only be used to protect the human cells against radiation, but possibly also to stabilize drugs or to increase the resistance of crop plants to environmental conditions like drought.

\section{WHAT WE HAVE LEARNED FROM WATER BEARS}

So, now you can see that those little water bears are quite different from the bears we know well. We have learned from these animals 
that they not only tolerate the most extreme conditions on our planet, they are even capable to survive in Space. Because of these unique properties, water bears are fascinating and among the most interesting model organisms for us to further study.

\section{ACKNOWLEDGMENTS}

The author thanks Sylvia Wiese and Jan Friesen for critically reading the manuscript.

\section{REFERENCES}

1. Jönsson, K. I. 2019. Radiation tolerance in tardigrades: current knowledge and potential applications in medicine. Cancers 11:1333. doi: 10.3390/cancers11 091333

2. Fontaneto, D. 2019. Long-distance passive dispersal in microscopic aquatic animals. Mov. Ecol. 7:10. doi: 10.1186/s40462-019-0155-7

3. Elleuche, S., Schröder, C., Stahlberg, N., and Antranikian, G. 2017. "Boiling water is not too hot for us!"- preferred living spaces of heat-loving microbes. Front. Young Minds. 5:1. doi: 10.3389/frym.2017.00001

4. Schröder, C., Burkhardt, C., Antranikian, G. 2020. What we learn from extremophiles. ChemTexts 6:8. doi: 10.1007/s40828-020-0103-6

5. Hashimoto, T., Horikawa, D. D., Saito, Y., Kuwahara, H., Kozuka-Hata, H., Shin, I. T., et al. 2016. Extremotolerant tardigrade genome and improved radiotolerance of human cultured cells by tardigrade-unique protein. Nat. Commun.

7:12808. doi: $10.1038 /$ ncomms12808

SUBMITTED: 17 June 2020; ACCEPTED: 02 July 2021;

PUBLISHED ONLINE: 29 July 2021.

EDITED BY: Stuart Semple, University of Roehampton London, United Kingdom

CITATION: Elleuche S (2021) Water Bears-The Most Extreme Animals on The Planet (And in Space!). Front. Young Minds 9:573691. doi: 10.3389/frym.2021. 573691

CONFLICT OF INTEREST: The author declares that the research was conducted in the absence of any commercial or financial relationships that could be construed as a potential conflict of interest.

COPYRIGHT @ 2021 Elleuche. This is an open-access article distributed under the terms of the Creative Commons Attribution License (CC BY). The use, distribution or reproduction in other forums is permitted, provided the original author(s) and the copyright owner(s) are credited and that the original publication in this journal is cited, in accordance with accepted academic practice. No use, distribution or reproduction is permitted which does not comply with these terms. 

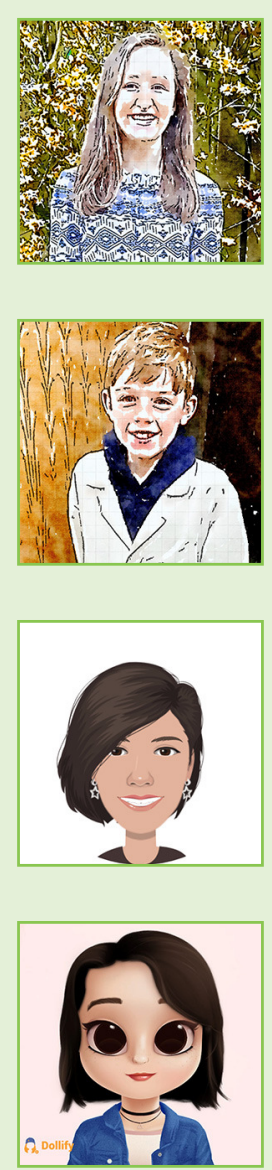

\section{MARGARIDA, AGE: 13}

My name is Margarida, I am 13 years old and I like reading, climbing, and writing. I love science, especially anything about black holes and I have absolutely no idea what I want to do when I grow up. I also really like biology.

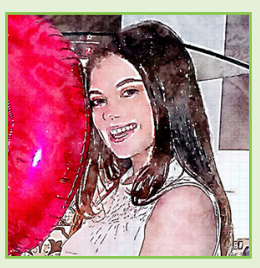

\section{MEGAN, AGE: 15}

$\mathrm{HI}$, I am Megan, my hobbies include musical theater, baking, and surfing (only during summer though!). I got involved with Frontiers for Young Minds as I really want to learn more about science and the world around me, so I thought reading these articles would be a good start!

\section{AUTHOR}

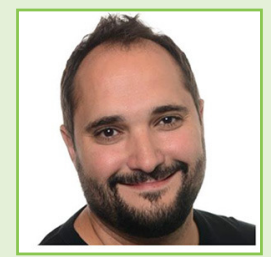

\section{SKANDER ELLEUCHE}

I am microbiologist/molecular biologist by training with an innate curiosity for all fields of biology. I have more than 10 years of experience working with microbes from extreme environments. I have designed comic book stories on science and have just written a popular science book on extreme environments, which is illustrated with cartoons (in German). Since 2020, I have worked as a scientist in a company that is developing assays for the detection of diseases and infections. Outside of work, I enjoy reading science stories and comic books and spending my leisure time with our cat, Leon. *skander.elleuche@rub.de 